\title{
SPATIO-TEMPORAL VARIATION IN THE DIET OF NORTHERN PIKE (Esox lucius) IN A COLONISED AREA (ESLA BASIN, NW SPAIN)
}

\author{
J. Dominguez and J.C. Pena \\ Department of Animal Biology. University of Leon. 24071 Leon, Spain.
}

\section{RESUMEN}

Se estudian los contenidos estomacales de 4.362 ejemplares de lucio (Esox lucius) capturados durante un periodo de seis aiios en la cuenca del Esla (Noroeste de Espaiia). Se han calculado la frecuencia y el porcentaje numérico de cada taxón presa para cada rio y mes separadamente.

El espectro de la dieta del lucio es muy amplio. Consumen presas pertenecientes a todos los grupos de invertebrados y vertebrados acuáticos. Demuestra ser un depredador generalista y la elevada diversidad y uniformidad de la dieta sugieren una escasa seleccidn del alimento.

El análisis de similaridad muestra que la composicidn de la dieta en los diferentes tramos de río es muy elevada. Sin embargo hay peculiaridades para cada tramo, debido a la presencia de presas accidentales. Por otra parte el porcentaje de estdmagos vacios fue elevado inmediatamente antes del periodo reproductor ( $84 \%$ en febrero) y desciende (12\% en mayo) cuando la reproducción ha finalizado. Las variaciones temporales muestran diferencias significativas.

Palabras clave: alimentación, lucio, Esox lucius, cuenca del rio Esla, Espaiia.

\begin{abstract}
The stomach contents of 4,362 northern pike (Esox lucius) captured over six years in the Esla Basin (NW of Spain) were examined. Thefrequency of occurrence and the numeric percentage of each taxon-prey was calculated separatelyfor each river and at monthly intervals.

The spectrum of the northern pike diet in the Esla Basin was very broad. They consume prey of all groups of aquatic invertebrates and vertebrates available. They are generalist predators. The high diversity and uniformity values of their diet suggests little,food selection.

The similarity shown in diet composition of pike in the different stretches is very high. However, diet in different stretches may differ due to the presence of accidental prey. The percentage of pike with empty stomachs in samples was highest before spawning (i.e. $84 \%$ in February) but dropped to $12 \%$ in May when reproduction had ended. Monthly variations in the percentage of pike with an empty stomach were statistically significant.
\end{abstract}

Keywords:feeding, northern pike, Esox lucius, Esla Basin, Spain.

\section{INTRODUCTION}

The colonisation of the Esla river basin has meant a paradigm in the colonising conduct of the species. The rapid occupation of a large number of water courses and adaptation to different hydrological regimes (regulated and natural rivers) as well as those of a different nature (reservoirs, lakes and rivers) demonstrates the extent of its success.

Pike was first detected in the Esla basin in 1964 in the Ricobayo reservoir (Pena, 1986). Between 450 and $500 \mathrm{~km}$ of water courses have been colonized in 30 years. The spread up-river has been recorded in other geographical areas by Snow (1974), Vostradowsky (1977) and Kipling (1983). 
On following up colonisation it can be seen that one part of the settled population goes to higher reaches. A reduced number of breeding adults colonises a new area causing a sub-population structure displaced towards small sizes, because of the recruitment effect. Large specimens capable of defending the territory and of forcing young ones to migrate, stay in the lowest reaches of the river basin. Homogenisation of sizes occurs when the population gets older. All this leads to size segregation as we go up the river courses of the basin. There is a tendency for sizes to decrease in the upper reaches, above all in the Porma and Orbigo rivers (Dominguez et al., 1989; Dominguez, 1996).

The voracity of this species has caused rather a lot of problems in the waters where it has been introduced. The impact on stocks of cyprinids and salmonids, as recorded by Arrignon (1966), Vooren (1972), Rincón et al. (1990) has encouraged measures from banning their introduction (Le Louarn \& Bagliniere, 1985) to population control (Larsen, 1966; Mann, 1985).

The trout character of most Esla basin rivers confers an added dimension to the introduction of this species. Pike control campaigns were carried out allowing us to obtain important information about the feeding habits of the colonising pike.

\section{MATERIAL AND METHODS}

\section{Study Sites}

The study area covers the south of the province of León and the north of the Zamora province. The hydrographic network from which samples were taken consists of the Esla, Porma, Moro, Orbigo, Tuerto, Jamuz, Eria, Cea and Tera rivers and the streams of La Almucera, El Castrón, Retuerta, Regato and Bonul. Only the streams and the Cea, Eria and Moro rivers are not regulated. The main river in the basin, the Esla, has since been regulated (i.e. from 1988) from its headwaters by the $664 \mathrm{hm}^{3}$ Riaiio reservoir, and by the Ricobayo reservoir $\left(1184 \mathrm{hm}^{3}\right)$ in its lower reaches. Figure 1 shows the sampling point locations.

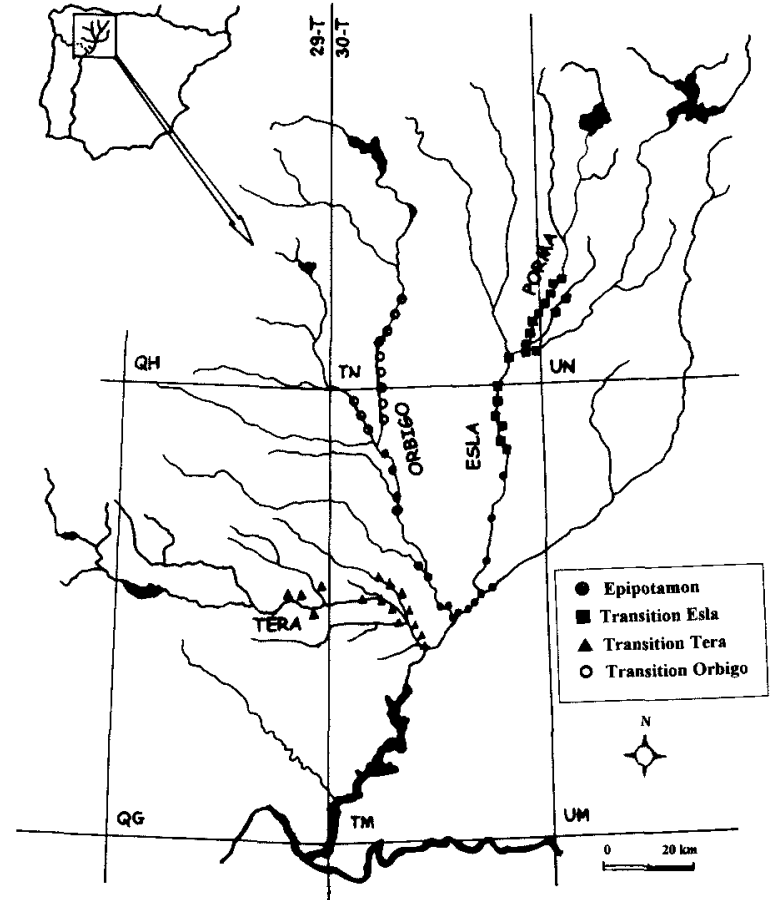

Figure 1. Location of the study area and sampling sites: a:Hiporhithron of the Esla river; $\mathbf{O}$ : hiporhithron of the Orbigo river; $\mathbf{A}$ : hiporhithron of the Tera river and $\bullet$ : epipotamon zone. Localización del urea de estudio y estaciones de muestreo. $\mathbf{0}$ : Hiporitron del rio Esla, O: Hiporitron del río Orbigo, A: Hiporitron del río Tera y Zona de epipotamon.

The sampling points have been grouped according to the classification of Illies \& Botosaneau (1963). Based on this classification, areas of the Esla (including the Esla itself and the Porma and Moro tributaries), the Orbigo (including the Orbigo and the Tuerto), the Tera and its tributary Castrón and Almucera streams are identified as hiporhithron zones. In the epipotamon area we have included: the Esla below Valencia de Don Juan, the Orbigo below La Baiieza until it joins the Esla, the Jamuz close to where it joins the Orbigo and the same areas of the Eria and the Tera below Mozar until the junction with the Esla. 


\section{Sampling techniques}

The sampling period was from January 1982 to September 1987. Sampling was at least monthly, except for the Tera transition stretch which was sampled in February, March and April (the prereproduction period). Specimens were captured using various methods: electric fishing, breeding traps and nets. To capture most speciments electrofishing was used at between 220 and $250 \mathrm{~V}$ and about 1.8A, depending on conductivity. The traps (Pena et al., 1991) were placed in streams and accesses to lagoons and still backwaters during the spawning period (between February and May), i.e. in La Almucera and El Castrón streams, the rivers Orbigo in Hospital, Porma in Marne and Villafruela, Moro in Puente Villarente and Jamuz in La Nora. When the excessive depth of the river course did not allow electrofishing, nets $(3 \mathrm{~cm}$ mesh size $)$ were put in place from a boat.

\section{Stomach content analysis}

A total of 4362 of the specimens caught were used for diet analyses. Specimens showing signs of regurgitation were rejected, in agreement with Treasurer (1988). These were minimal as electrofishing avoids regurgitation (Windel \& Bowen, 1978).

Stomach extraction was immediately after capture to avoid continued digestion of the prey (Windell \& BoweN, 1978). The preserving agent was $8 \%$ formaline. This causes the tissue of the stomach wall to harden, facilitating identification (Sorbe, 1972).

Although prey determination was carried out at the lowest taxonomic level possible (species or genus), the results are expressed by grouping them in higher taxa as this makes them easier to compare (Bowen, 1984). Feeding intensity is measured as a percentage of stomachs containing food. The importance of each prey was assessed in relation to its presence percentage in the diet (frequency of occurrence shown as $\% \mathrm{~F}$ ). The result is expressed as a percentage of the total number of specimens containing some type of prey (Windell \& Bowen, 1978) and its numerical representation based on the total prey caught. The resulting values are expressed as a percentage of the total number of prey captured (\% abundance) and is shown as \%N. Prey classification is as proposed by Sorbe (1972). In order to evaluate the significance of each prey in the pike diet, using the two descriptors (frequency of occurrence and abundance) together, the graph method proposed by Costello (1990) has been used. That of Tokeshi (1991) has been used to interpret the feeding strategy on the basis of graphic analysis.

Diet diversity was calculated using the Shannon expression (Shannon \& Weaver, 1949). Uniformity (Pielou, 1966) and heterogeneity (Margalef, 1972) were estimated from the diversity value.

The diet affinity between the different stretches studied was estimated using the Sorensen (1948) index. The affinity dendogramme was drawn with the results of this index according to the UPGMA method (Sneath \& Sokal, 1973).

The relationship between diets of pike in the different stretches and months was quantitatively evaluated using the Pearson correlation coefficient (Sokal \& Rohlf, 1981). Normality was tested using the David et al. (1954) rapid test.

Dependence or correspondence among the stretches studied and the prey ingested was studied by a factorial analysis of correspondences (FAC) (Dervin, 1988; Weber, 1991). The axes of the figure obtained with this statistical analysis explain part of the variance, measured as an "inertia percentage". Participation of the data in the inertia of each axis is given by the contribution of each (Deselle, 1990). The FAC was done using the BIOMECO statistics programme designed at the Montpellier CNRS by J. D. Lebreton, M. Roux, G. Banco \& A. M. Bancou.

To estimate the differences in temporal and spatial evolution of stomachs with contents and diet composition in the different stretches the $\chi^{2}$ statistic was used (Steel \& Torrie, 1985). To evaluate the differences in size distribution of the specimens captured, an analysis of variance was carried out. The Duncan test was then done to discover terms were mainly responible for significance. 
Table 1. Frequency of occurrence $(7 \mathrm{cF})$ and abundance $(7 \mathrm{cN})$ of each item prey in the and areas studied $(\mathrm{CC}=$ number of stomach with contents; $\mathbf{V A}=$ number of empty guts). Frecuencia de aparicidn $(\% F)$ y abundancia $(\% N)$ de cada presa en los tramos estudiados $(C C=$ número de estdmagos con contenido; $\mathbf{V A}=$ número de estdmagos vacios).

\begin{tabular}{|c|c|c|c|c|c|c|c|c|}
\hline \multirow[t]{2}{*}{$\begin{array}{l}\mathrm{CC} \\
\mathrm{VA}\end{array}$} & \multicolumn{2}{|c|}{$\begin{array}{c}\text { Epipotamon } \\
204 \\
187\end{array}$} & \multicolumn{2}{|c|}{$\begin{array}{r}\text { Esla } \\
719 \\
339\end{array}$} & \multicolumn{2}{|c|}{$\begin{array}{l}\text { Orbigo } \\
819 \\
357\end{array}$} & \multicolumn{2}{|c|}{$\begin{array}{c}\text { Tera } \\
268 \\
14690\end{array}$} \\
\hline & $\% \mathrm{~F}$ & $\% \mathrm{~N}$ & $\% \mathrm{~F}$ & $\% \mathrm{~N}$ & $\% \mathrm{~F}$ & $\% \mathrm{~N}$ & $\% \mathrm{~F}$ & $\% \mathrm{~N}$ \\
\hline Bivalvia & & & 0.14 & 0.05 & 0.12 & 0.04 & 0.37 & 0.46 \\
\hline Gastropoda & 0.98 & 0.92 & 1.95 & 0.49 & 2.69 & 1.81 & 0.37 & 0.11 \\
\hline Oligochaeta & 1.47 & 0.55 & 1.67 & 0.49 & 1.59 & 0.70 & 0.37 & 0.11 \\
\hline Hirudinea & 1.96 & 0.73 & 7.10 & 2.50 & 8.30 & 5.99 & 14.18 & 8.12 \\
\hline Cladocera & 3.43 & 3.67 & 8.50 & 1100 & 1.10 & 1.06 & 0.37 & 0.11 \\
\hline Ostracoda & & & 0.56 & 0.22 & & & & \\
\hline Amphipoda & 11.76 & 11.19 & 3.20 & 1.43 & 7.69 & 18.15 & 1.12 & 2.17 \\
\hline Decapoda & 1.47 & 0.55 & & & & & & \\
\hline Isopoda & & & & & & & 9.70 & 14.07 \\
\hline Arachnida & 0.49 & 0.18 & 0.70 & 0.14 & & & & \\
\hline Ephemeroptera & 6.37 & 11.19 & 21.87 & 12.37 & 11.11 & 12.91 & 6.72 & 5.26 \\
\hline Zygoptera & 13.73 & 15.60 & 36.91 & 36.01 & 6.35 & 5.64 & 8.96 & 4.92 \\
\hline Anisoptera & 10.78 & 4.22 & 7.66 & 2.36 & 1.34 & 0.48 & 6.72 & 3.32 \\
\hline Plecoptera & 0.49 & 0.18 & 1.67 & 0.41 & 0.24 & 0.18 & 9.70 & 4.81 \\
\hline Heteroptera & 5.88 & 12.29 & 2.92 & 2.31 & 1.59 & 0.70 & 10.82 & 10.41 \\
\hline Homoptera & & & 0.14 & 0.03 & & & & \\
\hline Megaloptera & 0.49 & 0.18 & 4.60 & 2.72 & 1.59 & 2.07 & 3.73 & 4.46 \\
\hline Coleoptera & 9.31 & 6.61 & 12.53 & 5.80 & 2.56 & 1.50 & 7.84 & 5.95 \\
\hline Lepidoptera & & & 0.14 & 0.03 & & & & \\
\hline Trichoptera & 1.47 & 0.55 & 2.92 & 1.02 & 2.20 & 1.37 & 6.34 & 2.75 \\
\hline Diptera & 1.47 & 2.57 & 6.96 & 3.46 & 2.08 & 2.86 & 2.61 & 0.92 \\
\hline Oncorhynchus mykiss & & & & & & & 0.75 & 0.23 \\
\hline Salmo trutta & 0.49 & 0.18 & 1.25 & 0.25 & 2.08 & 0.7 .5 & 0.75 & 0.23 \\
\hline Esox lucius & 0.98 & 0.37 & 2.92 & 0.58 & 0.49 & 0.18 & 10.07 & 3.09 \\
\hline Barbus bocagei & 9.80 & 4.04 & 2.65 & 0.52 & 3.30 & 1.23 & 10.45 & 6.18 \\
\hline Cyprinus carpio & 1.47 & 0.55 & 0.14 & 0.03 & & & & \\
\hline Chondrostoma polylepis & 22.55 & 9.91 & 4.60 & 1.24 & 10.01 & 4.32 & 11.94 & 7.44 \\
\hline Gobio gobio & 7.84 & 3.8 .5 & 5.15 & 1.46 & 11.60 & 5.20 & 24.25 & 9.61 \\
\hline Leuciscus carolitertii & 1.96 & 0.73 & 0.97 & 0.36 & 1.95 & 0.79 & 0.37 & 0.11 \\
\hline Rutilus arcasii & 8.33 & 4.40 & 20.47 & 10.23 & 39.44 & 19.43 & 5.22 & 2.63 \\
\hline Tinca tinca & & & 0.56 & 0.11 & 0.12 & 0.04 & 0.75 & 0.34 \\
\hline Cobitis calderoni & 0.49 & 0.18 & 3.62 & 1.10 & 14.29 & 10.31 & & \\
\hline Gambusia holbrooki & & & & & 0.24 & 0.09 & 0.37 & 0.11 \\
\hline Micropterus salmoides & 2.94 & 1.10 & 0.28 & 0.05 & & & & \\
\hline Unidentified fish & 5.39 & 2.02 & 2.79 & 0.58 & 1.95 & 0.88 & 3.73 & 1.26 \\
\hline Amphibia & & & 2.23 & 0.49 & 2.44 & 1.32 & 1.87 & 0.57 \\
\hline Reptilia & 0.49 & 0.18 & 0.14 & 0.03 & & & & \\
\hline Aves & 0.49 & 0.73 & & & & & & \\
\hline Mammalia & 1.47 & 0.55 & 0.84 & 0.16 & & & 0.75 & 0.23 \\
\hline
\end{tabular}

\section{RESULTS}

\section{Spatial variability}

Table 1 shows the results obtained when considering the origin of captured specimens as regards the pre-established areas or stretches of the Esla, Orbigo, Tera and epipotamon. Shown are the frequency of occurrence and numerical percentages, respectively, for each taxon considered. $67.96 \%$ of the stomachs contained some food of the 1058 

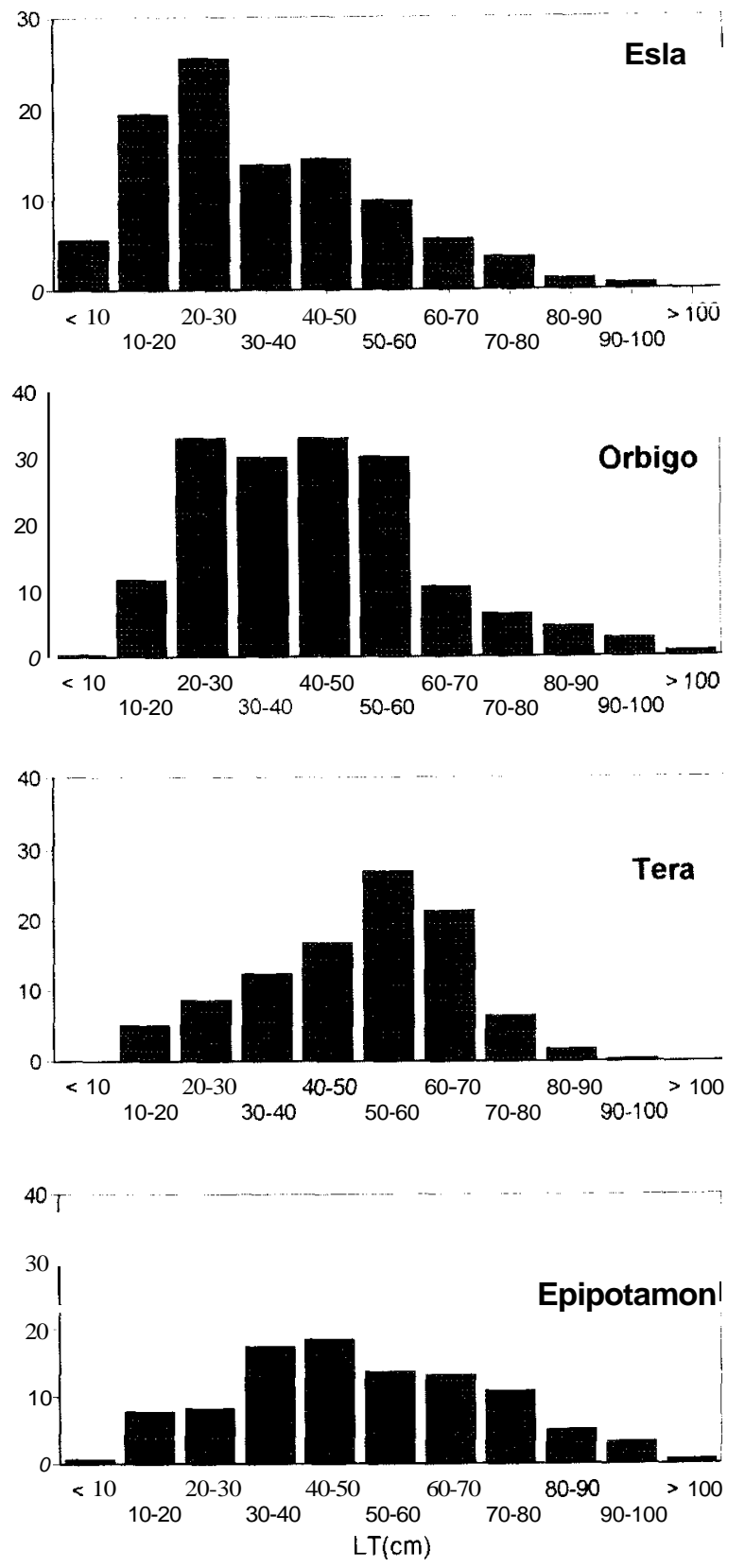

Figure 2. Percentage representation of each size range in the areas studied. Representación porcentual de cada rango de talla en las zonas consideradas.

specimens examined from the stretch named Esla. In the same zone of the Orbigo, 1176 were captured and $69.64 \%$ of guts contained food, whilst only $15.43 \%$ of the 1737 specimens from the Tera and $52.17 \%$ of the 391 from the epipotamon zone did. It has to be pointed out that those from the Tera stretch only belong to the reproductive period, which could explain their low ingestion level whilst specimens from the rest of the studied stretches correspond to captures made during the whole year.

The diet is widely distributed among the different prey-taxa in all cases with no marked preferences appearing. No prey can be included in the preferential category and a reduced number of taxa makes up the secondary one so the rest of prey would be taken randomy, according to the classification used. However, food use shows some peculiarities in diet richness as well as its composition in the different study areas. Richness, considered as the number of prey taxa, attains its highest value in the Esla stretch with 34 of the total of 39 taxa appearing in the whole diet spectrum. In decreasing order, as far as the number of taxa consumed is concerned, the epipotamon area, where about 30 taxa-prey were consumed, comes next, then the Tera with 29 and the Orbigo with 27.

The peculiarities of diet composition in each area can partly be explained by the sizes of the pike captured in different areas as there is a quite defined size segregation between areas.

Regarding this, the size distribution in each of the areas studied must be emphasised. Figure 2 shows the percentage representation of each size range in the areas studied. The results of the analysis of variance are:

\begin{tabular}{lccc} 
& Epipotamon & Esla & Tera \\
\hline Esla & $\mathrm{P}<0.01$ & & \\
\hline Tera & $\mathrm{NS}$ & $\mathrm{P}<0,01$ & \\
\hline Orbigo & $\mathrm{P}<0.01$ & $\mathrm{NS}$ & $\mathrm{P}<0.01$ \\
\hline
\end{tabular}

The graph in figure 3 shows which are the most relevant prey in each area (Costello, 1990). Almost all the points represented gather close to the co-ordinate origin. This method interprets 

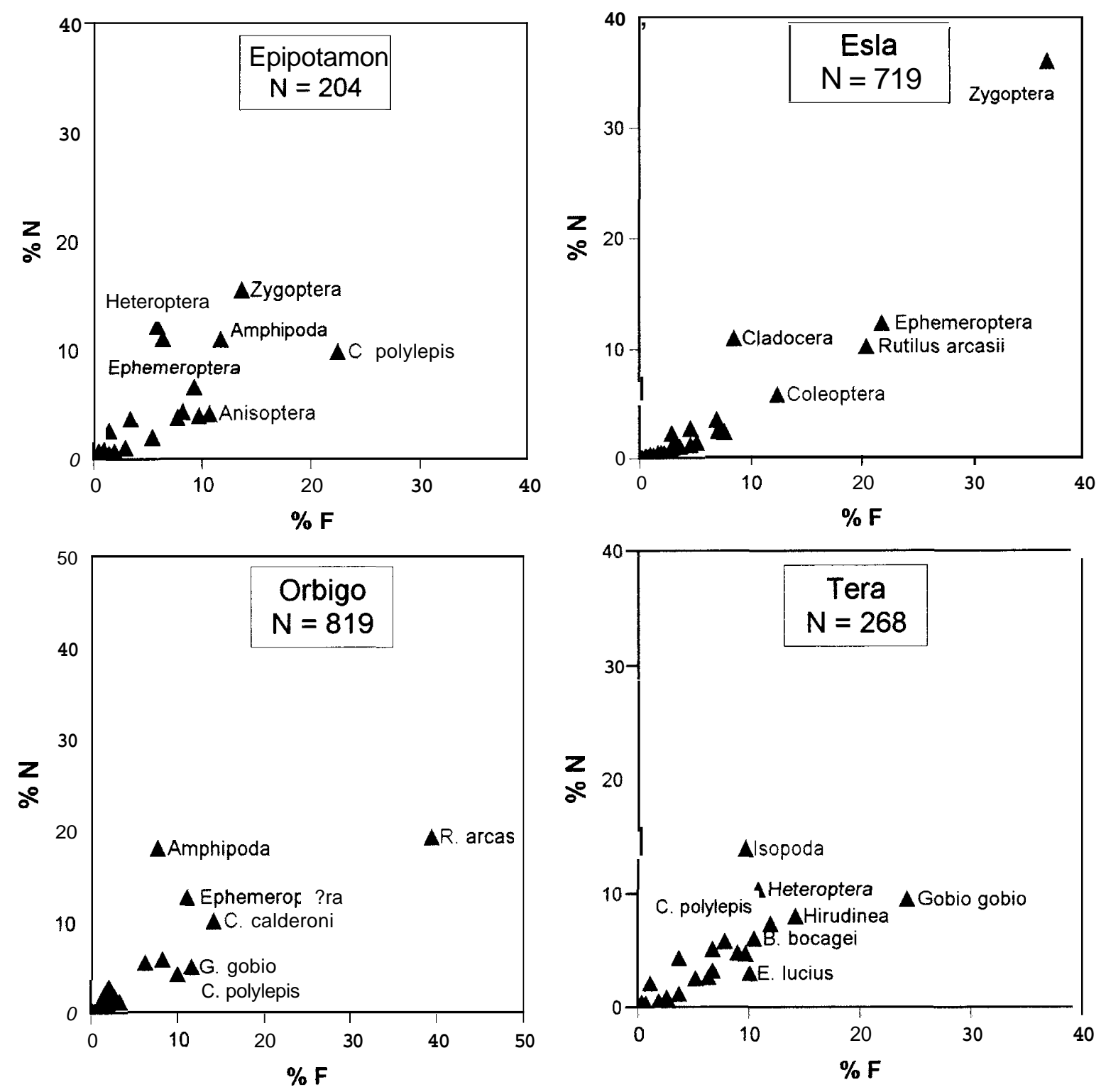

Figure 3. Prey taxa over $10 \%$ (frequency of occurrence and abundance) for each stretch studied. Taxones presa con valor superior al 10\% en cada uno de los dos métodos utilizados (frecuencia de aparicidn y abundancia), para cada tramo estudiado.

them as rare prey as regards their importance in the diet. As was previously mentioned, most of the prey are in the accidental category according to the Sorbe classification. The pike diet thus consists of numerous prey with low representation. The location of points in the lower part of the axis, which shows abundance, allows the diet of this species to be interpreted as generalist (Tokeshi, 1991)in the study area. The only exception worth mentioning would be the ingestion of Zygoptera in the hiporhithron area of the Esla.

Taxa richness values between 27 in the Orbigo area and 34 in the more generalist Esla, based on a total of 39 possible prey-taxa, are obtained after 
calculating diversity and its components. $\mathrm{H}^{\prime}$ diversity varies between 3.32 in the Esla and 4 in the Tera. The estimated heterogeneity $(0.24)$ is small, indicating great diet homogeneity in the study areas, Both diversity and uniformity in the stretches attain the highest values in the Tera stretch and the barbel area, where there is a more homogeneous representation of all the sizes of pike. It is slightly lower in those stretches in which size distribution is more restricted, the Orbigo and the Esla, in this order. The greater frequency and abundance of small prey (mainly invertebrates) in the Esla stretch could also be explained by this.

On the other hand, the Sorensen affinity index also shows that the diet in the four areas is qualitatively very similar. It defines two blocks, the first being the Orbigo and the Tera with $92.86 \%$ affinity, the second the two remaining stretches, the epipotamon and the Esla with $87.5 \%$. These two groups together have an affinity of $81.62 \%$ (Fig. 4)

In order to carry out the quantitative analysis of proximity among the diets of the study areas, the linear correlation for the numerical percentage of each prey was calculated between each possible pair of areas. The calculated correlation significance was always high $(\mathrm{p}<0.01$, except the Tera-Orbigo with $\mathrm{p}<0.05$ ), which shows the similarity between the diets in the areas studied.

Diet proximity is shown graphically by the FAC carried out using the relative frequency of each taxon prey.

The Esla stretch is in a possition that reveals greater generalization, as can be seen on axes 1 and II of this analysis, with 45.8 and $30.3 \%$ of inertia, respectively (Fig. 5). Prey widely represented in this area (i.e. within the line of dashes) are around it but all those within the line of points also have the same characteristics. Very few prey taxa are absent from the diet of the pike in this stretch, and all have low representation even in the areas they characterise.

The prey included in the triangle defined by the Tera, Orbigo and epipotamon areas (shown as $\mathrm{T}, \mathrm{O}$ and $\mathrm{B}$, respectively) are present in the three areas, and to a greater extent the closer they are to
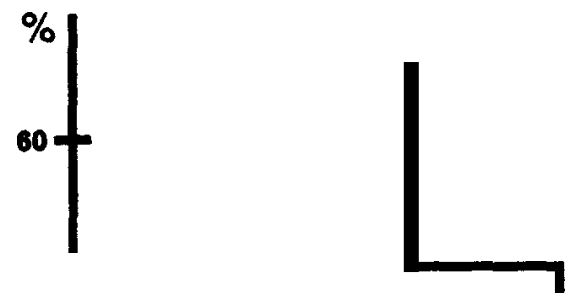

\section{Orbigo Tera Esla Epipotamon}

Figure 4. Dendrogramme showing the affinity between the stretches studied. Dendrograma de afinidudes entre los tramos considerados.

each area. Esla (E) is in an intermediate position between epipotamon and Orbigo as far as axis I is concerned. Orbigo and Tera differ most, as already shown by the correlations carried out, and coincide in characteristics with low stretches of the epipotamon.

Singularity is marked by those prey that are differentiated towards the extremes of the graph, defining that area to which they are closest.

Axes I and III (with inertia percentages of 45.77 and 23.91, respectively) (Fig. 6) show taxa identifying the Esla stretch (situated within the solid line). As had been seen on previous occasions, they are accidental prey except for the Zygoptera, which reached high values, but are present in all the other areas.

In spite of the similarity shown in diet composition of the different stretches there are peculiarities due to the presence of prey, mostly accidental, which characterise certain stretches. This can be observed in Table 1 and in the FAC.

Both diversity and uniformity of stretches reach higher values in the Tera stretch and the epipotamon area, where there is a more uniform representation of all sizes of pike. These indices are slightly lower in those stretches in which size distribution is more restricted, i.e. the Orbigo and the Esla, in this order. The greater frequency and abundance of small prey (basically invertebrates) 


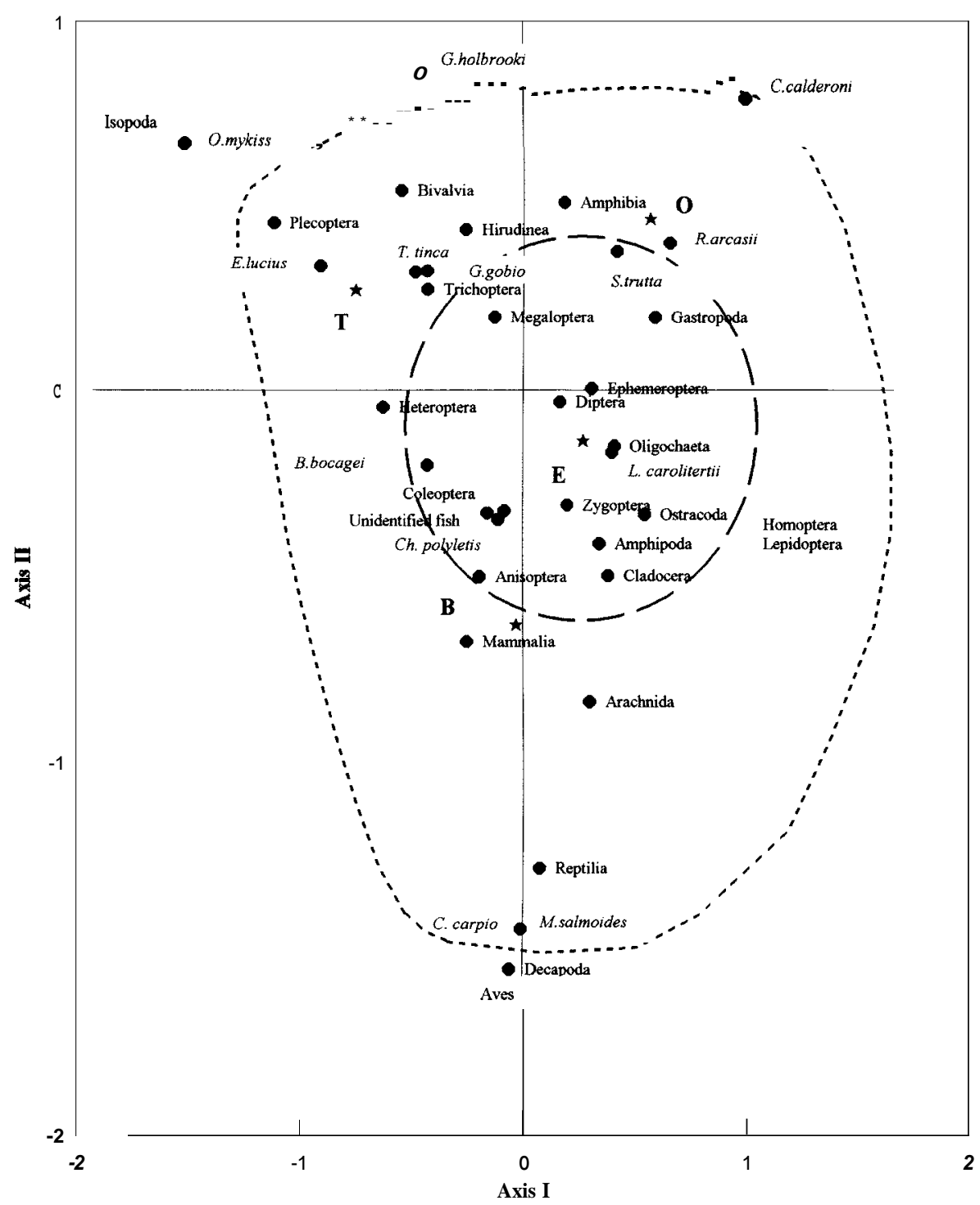

Figure 5. Factorial correspondence analysis results. The dotted line encloses prey from the Esla hiporhithron stretch (more generalist diet) and the broken line encloses those more frequent. Inertia percentage of axes $\mathrm{I}=45.77$ and II $=30.72$. Resultados del análisis factorial de correspondencius. La línea de puntos incluye la dietu del hiporitron del Esla (la mas generalistu) y la línea de trazos las presas con mayor frecuencia de aparición. Porcentaje de inercia de los ejes: $I=45,77$ y $I I=30,72$.

in the Esla stretch could also be the similarly explained.

Pike of the Tera (Fig. 5 ) are characterised by the ingestion of rainbow trout (Oncorhynchus mykiss), isopods, plecoptera and pike. As far as rainbow trout are concerned it is the only area where its presence coincides with the pike distri- bution areas, particularly in the intensive fishing reserve of the Tera river. However, ingestion of this species by pike is minimal. The isopods only appear diets in this stretch, in proportions close to $10 \%$ and are difficult to explain, despite being mentioned frequently in the literature. The plecoptera and pike, although forming part of the 


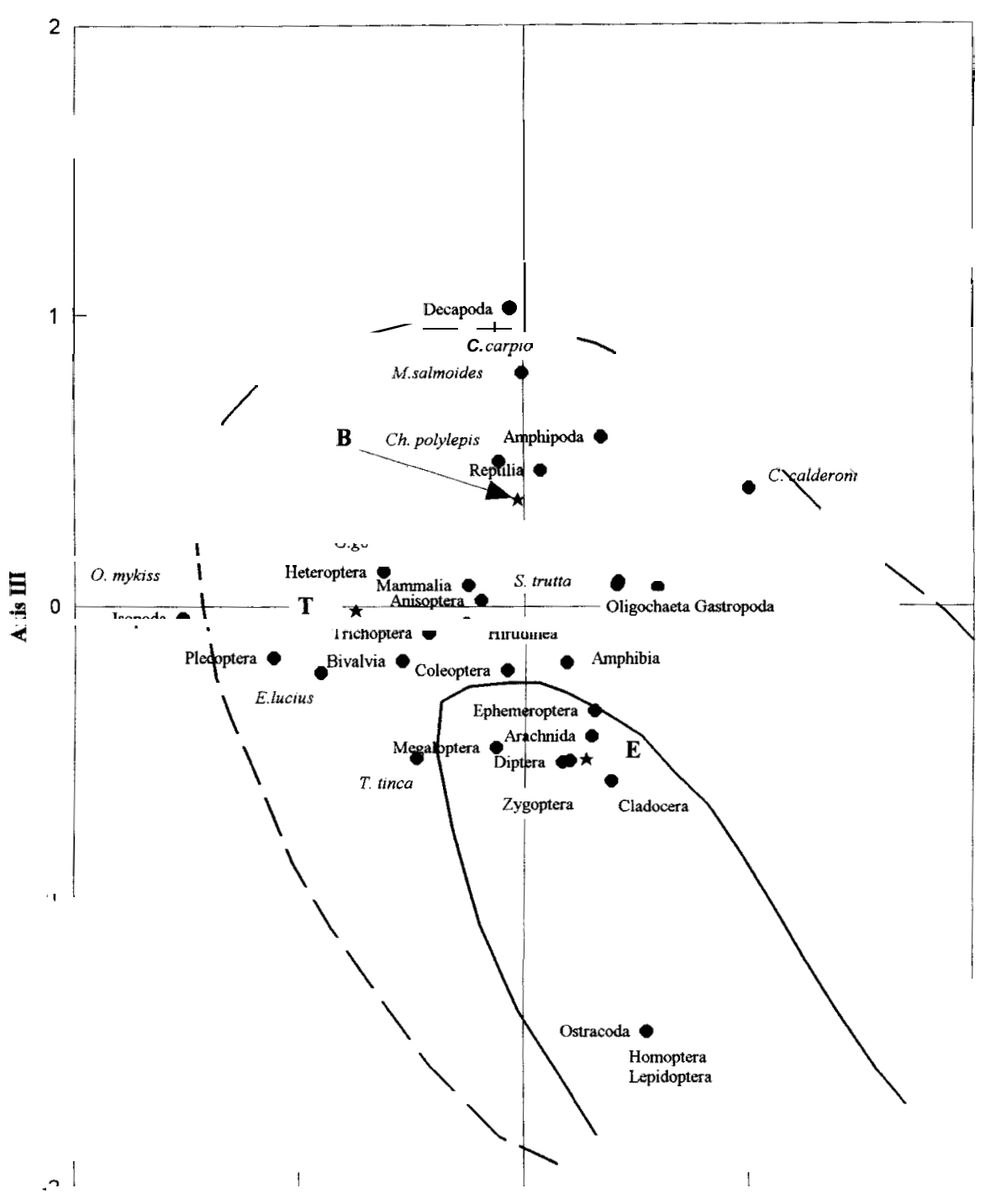

diet of pike in all stretches studied, are more relevant in this particular one.

The stretch called Orbigo is characterised by the greater presence of loach, although this species is also present to a lesser degree in the
Esla and the epipotamon area, and absent from the Tera. Velasco (1994) refers to a decrease of this species in the area. Red roach is also ingested more in the Orbigo than in the other stretches, although it is present in all of them. 
Mosquitofish (Gambusia holbrooki) is present in the two stretches although referred to in small numbers. The fact that this species lives in very shallow waters, not at all suitable for pike, could explain its low scarcity.

The epipotamon area is characterised by very incidental prey. Birds and decapods are the only differential prey. In the two cases, contribution to the diet of pike is minimal. The ingestion of birds is pure chance and the decapods found have been those belonging to the Procambarus genera which was starting to colonise the study area during the samplings - and Palaemonetes, with a restricted distribution area. Arachnida, Carp (Cyprinus carpio), black-bass (Micropterus salmoides), reptiles, and mammals also contribute to differentiation of diet in this area. All of them have very low representation and their presence always coincides in the Esla stretch.

The peculiarities of the Esla can be seen in figure 5. Ostracoda, Homoptera and Lepidoptera are the only prey present in this area alone and always with minimal representation. The Cladocera, Diptera, Ephemeroptera and Zygoptera are clearly more frequent in this stretch, although were pre- sent in all those studied.

In a sequence of characteristics the most different areas although still quite similar (Figs. 5 and 6) would be the Orbigo and the Tera, as demonstrated by their separation in relation to plane I. Both are close to the epipotamon area and close to the Esla area.

The similarity shown by the analyses carried out allows the specimens of all the study areas to be grouped for evaluating seasonal variations in diet.

\section{Seasonal variations in diet}

The percentage of stomachs with any contents in the different months (Fig. 7) are shown by a line with two clearly defined periods: a pre-spawning period during February with a minimum of $16.4 \%$, which begins to recover in March and April when breeding occurs. This indicates that feeding begins immediately afterwards. Maximum feeding intensity ( $88 \%$ ) is reached in May and continues to be high in the following months. The variations throughout the year differ significantly $(\mathrm{p}<0.05)$.

Tables 2 and 3 show the variation of the representation reached by each taxon based on the

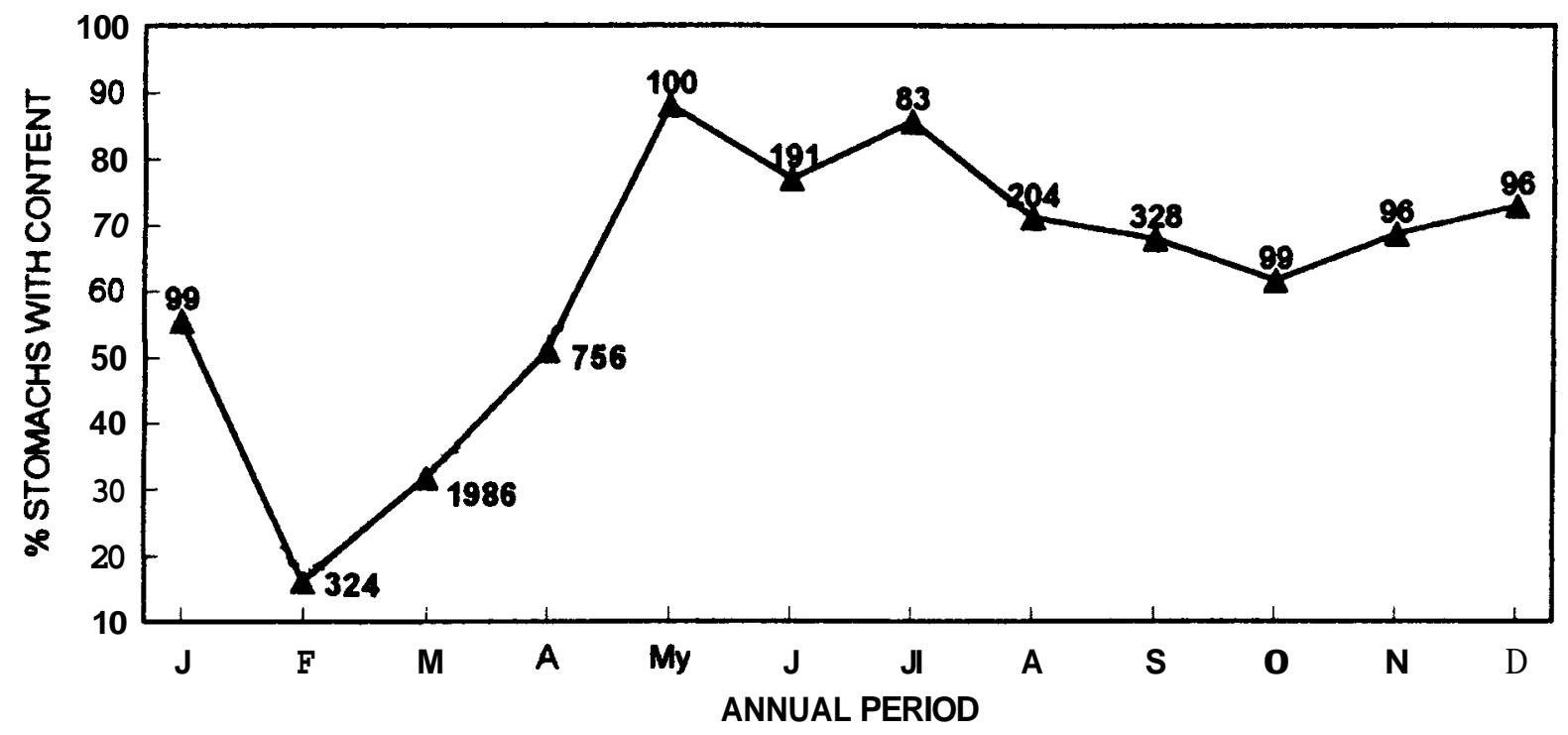

Figure 7.Monthly variation in the percentage of stomachs with content. Number shows the total analysed individuals. Varincidnmensual del porcentuje de estómagos con contenido. Los números indican el total de ejemplares examinados. 
Table 2. Monthly variation in frequency of occurrence of each prey item. Vuriucidnmensual de la frecuencia de aparición de cada presa.

\begin{tabular}{|c|c|c|c|c|c|c|c|c|c|c|c|c|}
\hline Prey category / \% F & January & February & March & April & May & June & July & August & Septemb & October & Novemb & Decemb \\
\hline Bivalvia & - & $-\ldots$ & 0.31 & - & 1.14 & - & - & - & - & - & - & - \\
\hline Gastropoda & - & 1.89 & 1.23 & 3.37 & 4.55 & 4.08 & 1.41 & - & 1.34 & - & 3.03 & 1.43 \\
\hline Oligochaeta & 9.09 & - & 1.54 & 0.78 & 3.41 & 2.04 & - & 2.07 & 0.45 & 1.64 & 1.52 & - \\
\hline Hirudinea & 3.64 & 1.89 & 7.23 & 10.62 & 3.41 & 10.88 & 7.04 & 2.01 & 14.73 & 9.84 & 3.03 & 1.43 \\
\hline Cladocera & - & 1.89 & 4.00 & 4.92 & 6.82 & 7.48 & 4.23 & - & - & 9.84 & 1.52 & 7.14 \\
\hline Ostracoda & - & - & 0.15 & - & - & 2.04 & - & - & - & - & - & - \\
\hline Amphipoda & 5.45 & 1.89 & 6.00 & 7.77 & 2.27 & 6.12 & 5.63 & 2.07 & 3.13 & 3.28 & 1.52 & 18.57 \\
\hline Decapoda & - & - & 0.15 & - & - & 1.36 & 一 & - & - & - & - & - \\
\hline Isopoda & - & - & 0.92 & 5.18 & - & - & - & - & - & - & - & - \\
\hline Arachnida & - & - & 0.31 & 0.52 & - & 1.36 & - & - & - & 1.64 & - & - \\
\hline Ephemeroptera & 1.82 & 3.77 & 8.46 & 17.10 & 50.00 & 27.89 & 28.17 & 8.97 & 8.48 & 27.87 & 4.55 & 5.71 \\
\hline Zygoptera & - & 11.32 & 27.23 & 15.03 & 43.18 & 36.05 & 12.68 & 2.07 & 1.19 & 22.95 & 7.58 & 14.29 \\
\hline Anisoptera & - & 1.89 & 8.46 & 8.03 & 5.68 & 4.08 & 2.82 & - & 0.89 & 4.92 & 1.52 & 1.43 \\
\hline Plecoptera & - & 7.55 & 3.23 & 2.85 & 1.14 & 1.36 & - & - & 0.45 & - & - & 2.86 \\
\hline Heteroptera & 1.82 & 5.66 & 3.69 & 8.29 & - & 3.40 & I. 41 & 2.07 & 2.23 & - & 1.52 & - \\
\hline Homoptera & - & - & - & - & - & - & - & - & - & I. 64 & - & - \\
\hline Megaloptera & 1.82 & - & 3.38 & 8.29 & - & 0.68 & - & - & - & 1.64 & - & 1.43 \\
\hline Coleoptera & 10.91 & 5.66 & 11.08 & 9.59 & 5.68 & 6.12 & 11.27 & - & - & 4.92 & 1.52 & 12.86 \\
\hline Lepidoptera & - & - & - & - & - & 0.68 & - & - & - & - & - & - \\
\hline Trichoptera & - & 5.66 & 3.38 & 6.22 & - & 2.04 & - & 0.69 & 0.45 & 1.64 & 1.52 & 4.29 \\
\hline Diptera & - & - & 3.54 & 5.70 & 5.68 & 11.56 & 1.41 & - & 4.02 & - & 一 & - \\
\hline Oncorhynchus mykiss & - & - & - & 0.52 & - & - & - & - & - & - & - & - \\
\hline Salmo trutta & - & 15.09 & 1.23 & 1.30 & 1.14 & - & 1.41 & 2.76 & - & I.64 & - & - \\
\hline Esoxlucius & - & 3.77 & 4.92 & 3.37 & 一 & 0.68 & 1.41 & 0.69 & 0.45 & 3.28 & 3.03 & - \\
\hline Barbus bocagei & 5.45 & 15.09 & 3.85 & 3.63 & 2.27 & 10.88 & 5.63 & 2.07 & 2.68 & 6.56 & 7.58 & 5.71 \\
\hline Cyprinus carpio & - & 1.89 & 0.46 & 0.26 & - & - & - & - & - & - & - & - \\
\hline Chondrostoma polylepis & 36.36 & 9.43 & 8.46 & 4.66 & 10.23 & 10.20 & 25.35 & 9.66 & 6.25 & 6.56 & 7.58 & 32.86 \\
\hline Gobio gobio & 10.91 & 16.98 & 9.85 & 13.99 & 9.09 & 8.16 & 7.04 & 15.17 & 10.71 & 1.64 & 12.12 & 2.86 \\
\hline Leuciscus carolitertii & - & 3.71 & 0.92 & 2.85 & - & - & 1.41 & 2.76 & 0.45 & 1.64 & - & 2.86 \\
\hline Rutilus arcasii & 25.45 & 15.09 & 20.00 & 27.46 & 13.64 & 3.40 & 9.86 & 53.10 & 39.29 & 13.11 & 66.67 & 2.86 \\
\hline Tinca tinca & - & - & 0.31 & 0.78 & 1.14 & - & - & - & 0.45 & - & - & - \\
\hline Cobitis calderoni & 3.64 & 1.89 & 2.71 & 4.92 & 9.09 & 6.12 & 15.49 & 11.72 & 25.45 & - & 1.52 & 1.43 \\
\hline Gambusia holbrooki & - & - & - & 0.26 & 2.27 & - & - & - & - & - & 一 & - \\
\hline Micropterus salmoides & 1.82 & - & 0.31 & - & 1.14 & - & - & 一 & - & 1.64 & 3.03 & - \\
\hline Unidentified fish & 7.27 & 7.55 & 3.23 & 2.59 & 1.14 & 2.04 & 2.82 & I. .38 & 0.89 & 8.20 & 4.55 & 4.29 \\
\hline Amphibia & - & - & 1.08 & 2.07 & 2.21 & 2.72 & 4.23 & 2.07 & 5.80 & 1.64 & 1.52 & - \\
\hline Reptilia & - & - & - & - & 1.14 & 0.68 & - & - & - & - & - & - \\
\hline Aves & - & - & - & - & - & - & - & - & 0.45 & - & 一 & - \\
\hline Mammalia & 一 & - & 0.46 & 0.26 & - & I. .36 & 2.82 & - & 0.45 & - & 3.03 & 1.43 \\
\hline Animal material & - & 1.89 & 0.92 & - & 1.14 & 4.76 & 1.41 & - & - & 4.92 & - & 5.71 \\
\hline Vegetable material & 3.64 & 1.89 & 7.85 & 6.99 & $4.5 \mathrm{~s}$ & 10.20 & 4.23 & 4.14 & 8.48 & 3.28 & 1.52 & 1.43 \\
\hline Mineral material & - & 1.89 & 0.15 & 1.04 & 1.14 & 0.68 & $\mathrm{I} .41$ & - & - & - & - & - \\
\hline
\end{tabular}


methods considered, frequency and numerical percentage, respectively, during the year.

The pike diet evolves irregularly on a monthly basis, both in the number of taxa represented and the contribution of each. So only one taxon (Zygoptera in February) is over 50\% in the numerical method. Few are over $25 \%$ : none in January, Zygoptera in March, May and June, Ephemeroptera in May and July, red roach (Rutilus arcasii) in August, loach (Cobitis calderoni) in September, Cladocera in October, red roach again in November and Amphipoda are those with the largest representation in December.

As far as the frequency method is concerned, and according to the Sorbe (1972) classification, preferential prey are rare: Ephemeroptera in May and red roach in August and November. Few taxa are on the secondary level (frequency percentage between $50 \%$ and $10 \%$ ).

The rest of the groups would be considered accidental prey, according to this classification. But continuity through time suggests that in reality they are rare because the high richness of diet causes a fractionation of this frequency, minimising their presence.

The Costello (1990) graph method allows those prey which stand out in each month to be appreciated. Few exceed $10 \%$ in either of the two methods (Fig. 8). The monthly changes in the representation of different groups shows no specific pattern. Again the location of points representing each of the prey are close to the co-ordinate origin, therefore prey denomination, according to Costello (1990), is once again "rare" as regards importance. Prey abundance rarely stands out and this suggests a generalist diet throughout the year, according to the interpretation proposed by Tokeshi (1991).

In the same way, no correlations were found between frequency of occurrence of each taxon ingested between any pair of months in any year. In the monthly correlative sequence, strong interactions can be observed from March to July (the significance levels of the correlations are very high) and are very similar. March and April values are strongly correlated with the other months. The greater availability of food in these months, as a result of hatching of many groups of invertebrates ingested), allows these periods of time to appear similar to the rest of the year. May and June show lower significance in their relation with the autumn and winter months. From August to December, or even January, the months can be more easily differentiated. There is probably lower food availability during these months and this would cause a more random ingestion of prey. February acts as a transition period with a certain connection with March and April. In addition to low prey biological activity at this time, it coincides with the period prior to reproduction, when less food is ingested.

Diversity is very high in every month, which once again verifies the generalist character of the diet of pike. On this occasion, the diversity values are influenced by the uniformity of food base. Richness reaches its maximum value (33 taxa) in March and minima in August (17 taxa) and January (14). The variations reflect the behaviour of prey invertebrates, whilst those of vertebrates are more attenuated.

\section{DISCUSSION}

\section{Diet intensity and composition}

As far as feeding intensity is concerned the results have shown that the Esla, epipotamon and Orbigo areas have a greater presence of food than the Tera for total specimens and for the periods in which they are comparable. Two circumstances concur on this stretch: specimens were only captured during the period prior to reproduction (February, March and April) and, in addition, most of the specimens captured were large so food ingestion was substantially reduced (Dominguez, 1996). The latter coincides with what has been described by other authors (Frost, 1954, Healy, 1956, Munro, 1957, Lawler, 1965, Holland \& Huston, 1984 and Champan et al., 1989).

Food ingestion throughout the year does not generally show any clear tendencies, although the relatively high proportion of stomachs containing food should be mentioned. The biblio- 
Table 3. Monthly variation in abundance (percentage) of each item prey. Variación mensual de la abundancia de cada presa.

\begin{tabular}{|c|c|c|c|c|c|c|c|c|c|c|c|c|}
\hline Prey category / \% F & January & February & March & April & May & June & July & August & Septemb. & October & Novemb. & Decemb \\
\hline Bivalvia & - & - & 0.23 & - & 0.19 & - & - & - & - & - & - & 一 \\
\hline Gastropoda & - & 0.50 & 0.38 & 1.71 & 1.33 & 1.05 & 0.54 & - & 0.61 & - & 0.70 & 2.35 \\
\hline Oligochaeta & 6.60 & - & 0.46 & 0.17 & 0.57 & 1.23 & - & 1.84 & 0.20 & 0.53 & 0.35 & - \\
\hline Hirudinea & 1.89 & 0.50 & 3.06 & 4.24 & 1.71 & 6.49 & 3.26 & 1.38 & 13.56 & 3.74 & 1.05 & 1.18 \\
\hline Cladocera & - & 0.50 & 6.72 & 4.19 & 2.66 & 8.95 & 2.17 & - & - & 25.67 & 24.39 & 2.94 \\
\hline Ostracoda & - & - & 0.15 & - & - & 0.70 & - & - & - & - & - & - \\
\hline Amphipoda & 3.77 & 0.50 & 8.75 & 11.29 & 0.38 & 2.11 & 2.72 & 5.53 & 2.23 & 6.95 & 0.35 & 28.82 \\
\hline Decapoda & - & - & 0.04 & - & - & 0.35 & - & - & - & - & - & - \\
\hline Isopoda & - & - & 0.65 & 5.84 & - & - & - & - & - & - & - & - \\
\hline Arachnida & - & - & 0.08 & 0.11 & - & 0.35 & - & - & - & 0.53 & - & - \\
\hline Ephemeroptera & 5.66 & 3.02 & 6.80 & 10.19 & 41.75 & 18.77 & 34.24 & 9.22 & 6.88 & 21.39 & 1.74 & 4.12 \\
\hline Zygoptera & - & 51.76 & 29.87 & 14.05 & 33.97 & 29.47 & 10.87 & 1.84 & 0.81 & 16.58 & 10.45 & 17.06 \\
\hline Anisoptera & - & 1.01 & 3.02 & 2.59 & 1.14 & 1.40 & 1.09 & - & 0.40 & 1.60 & 0.35 & 0.59 \\
\hline Plecoptera & - & 3.52 & 1.41 & 0.72 & 0.19 & 0.35 & - & - & 0.20 & - & - & 1.18 \\
\hline Heteroptera & 0.94 & 2.01 & 4.24 & 6.06 & - & 3.33 & I.09 & 1.38 & 1.42 & - & 0.35 & - \\
\hline Homoptera & - & - & - & - & - & - & - & - & - & 0.53 & - & - \\
\hline Megaloptera & 3.77 & - & 1.53 & 5.56 & - & 0.18 & - & - & - & 1.07 & - & 1.76 \\
\hline Coleoptera & 15.09 & 2.01 & 6.46 & 5.23 & 1.33 & 2.98 & 5.98 & - & - & 2.14 & 0.35 & $\mathrm{~J} 0.59$ \\
\hline Lepidoptera & - & - & - & - & - & 0.18 & - & - & - & - & - & - \\
\hline Trichoptera & - & 5.53 & 1.30 & 2.20 & - & 0.53 & - & 0.46 & 0.20 & 0.53 & 0.35 & 1.76 \\
\hline Diptera & - & - & 1.72 & 4.52 & 0.95 & 5.26 & 0.54 & - & 10.12 & - & - & - \\
\hline Oncorhynchus mykiss & - & - & - & 0.11 & - & - & - & - & - & - & - & - \\
\hline Salmo trutta & - & 4.02 & 0.31 & 0.28 & 0.19 & - & 0.54 & 1.84 & - & 0.53 & - & - \\
\hline Esox lucius & - & 1.01 & 1.22 & 0.72 & - & 0.18 & 0.54 & 0.46 & 0.20 & 1.07 & 0.70 & - \\
\hline Barbus bocagei & 2.83 & 5.53 & 1.45 & 1.43 & 0.38 & 2.98 & 2.17 & 1.38 & 1.21 & 2.14 & 1.74 & 2.35 \\
\hline Cyprinus carpio & - & 0.50 & 0.11 & 0.06 & - & - & - & - & - & - & - & - \\
\hline Chondrostoma polylepis & 21.70 & 4.02 & 3.21 & 1.43 & 2.85 & 3.51 & 11.41 & 6.91 & 3.24 & 2.14 & 2.09 & 18.24 \\
\hline Gobio gobio & 5.66 & 5.03 & 3.59 & 3.69 & 2.09 & 3.33 & 4.89 & 11.06 & 5.06 & 0.53 & 3.14 & 1.76 \\
\hline Leuciscus carolitertii & - & 1.01 & 0.46 & 0.72 & - & - & 0.54 & 1.84 & 0.20 & 0.53 & - & 1.18 \\
\hline Rutilus arcasii & 24.53 & 5.53 & 10.47 & 9.09 & 4.93 & 1.40 & 3.80 & 39.17 & 21.26 & 7.49 & 48.08 & 1.18 \\
\hline Tinca tinca & - & - & 0.08 & 0.22 & 0.19 & - & - & - & 0.20 & - & - & - \\
\hline Cobitis calderoni & 2.83 & 0.50 & 0.92 & 2.37 & 2.09 & 2.98 & 9.24 & 11.06 & 26.92 & - & 0.35 & 0.59 \\
\hline Gambusia holbrooki & - & 一 & - & 0.06 & 0.38 & - & - & 一 & - & - & - & 一 \\
\hline Micropterus salmoides & 0.94 & - & 0.08 & - & 0.19 & - & - & - & - & 0.53 & 0.70 & - \\
\hline Unidentified fish & 3.77 & 2.01 & 0.84 & $0.6 \mathrm{I}$ & 0.19 & 0.53 & 1.63 & 0.92 & 0.40 & 3.21 & 1.74 & 1.76 \\
\hline Amphibia & - & - & 0.31 & 0.44 & 0.38 & 0.88 & 1.63 & 3.69 & 3.64 & 0.53 & 0.35 & - \\
\hline Reptilia & - & - & - & - & 0.19 & 0.18 & - & - & - & - & - & - \\
\hline Aves & - & - & 一 & - & - & - & - & - & 0.81 & - & - & 一 \\
\hline Mammalia & - & - & 0.11 & 0.06 & - & 0.35 & 1.09 & - & 0.20 & - & 0.70 & 0.59 \\
\hline
\end{tabular}



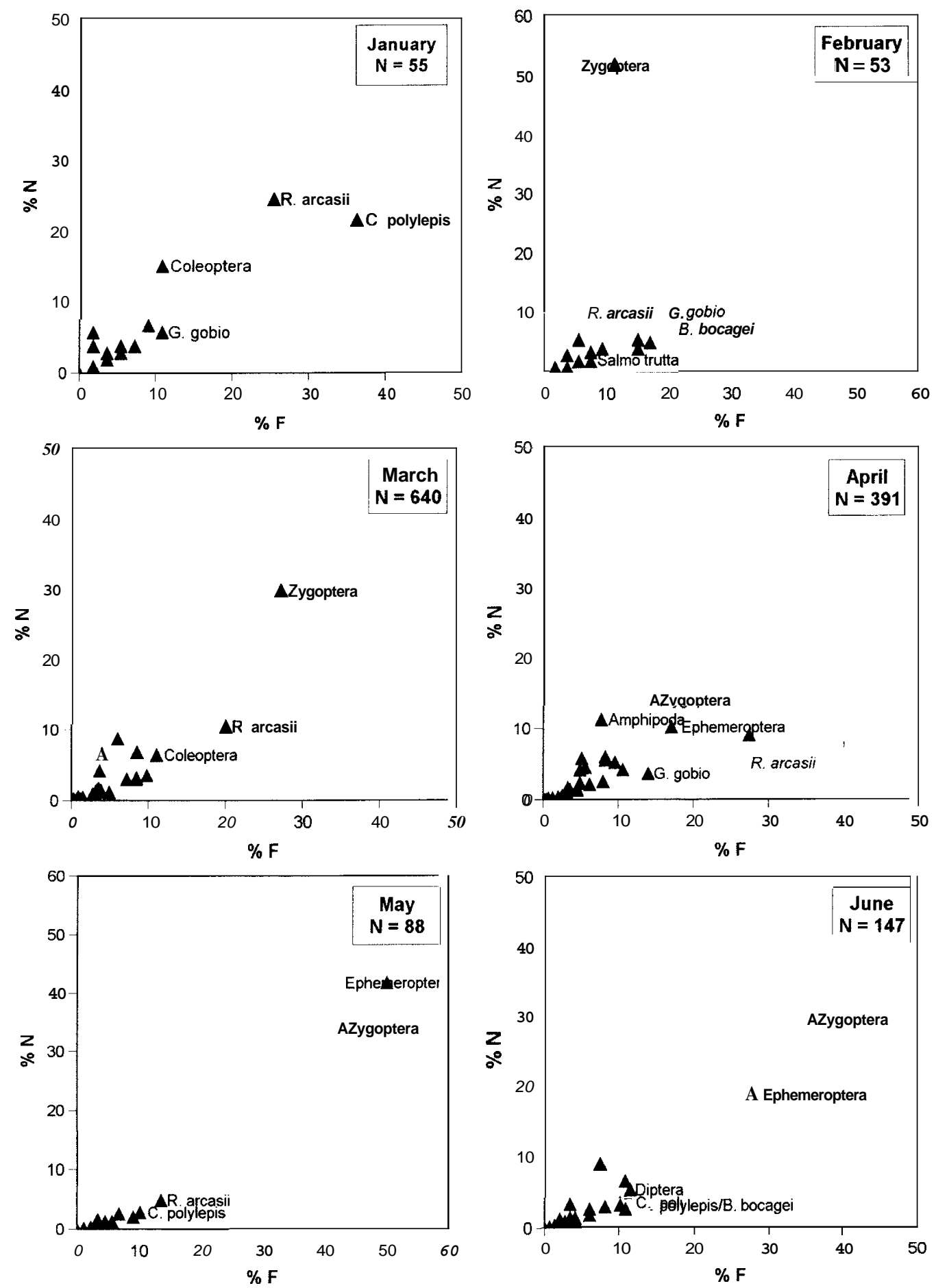

Figure 8. Prey taxa over $10 \%$ (frequency of occurrence and abundance) through the annual period. Taxones presa con valor superior al $10 \%$ en cada uno de los dos métodos utilizados (frecuencia de aparición y abundancia), durante el periodo anual. 
The diet of Northern pike
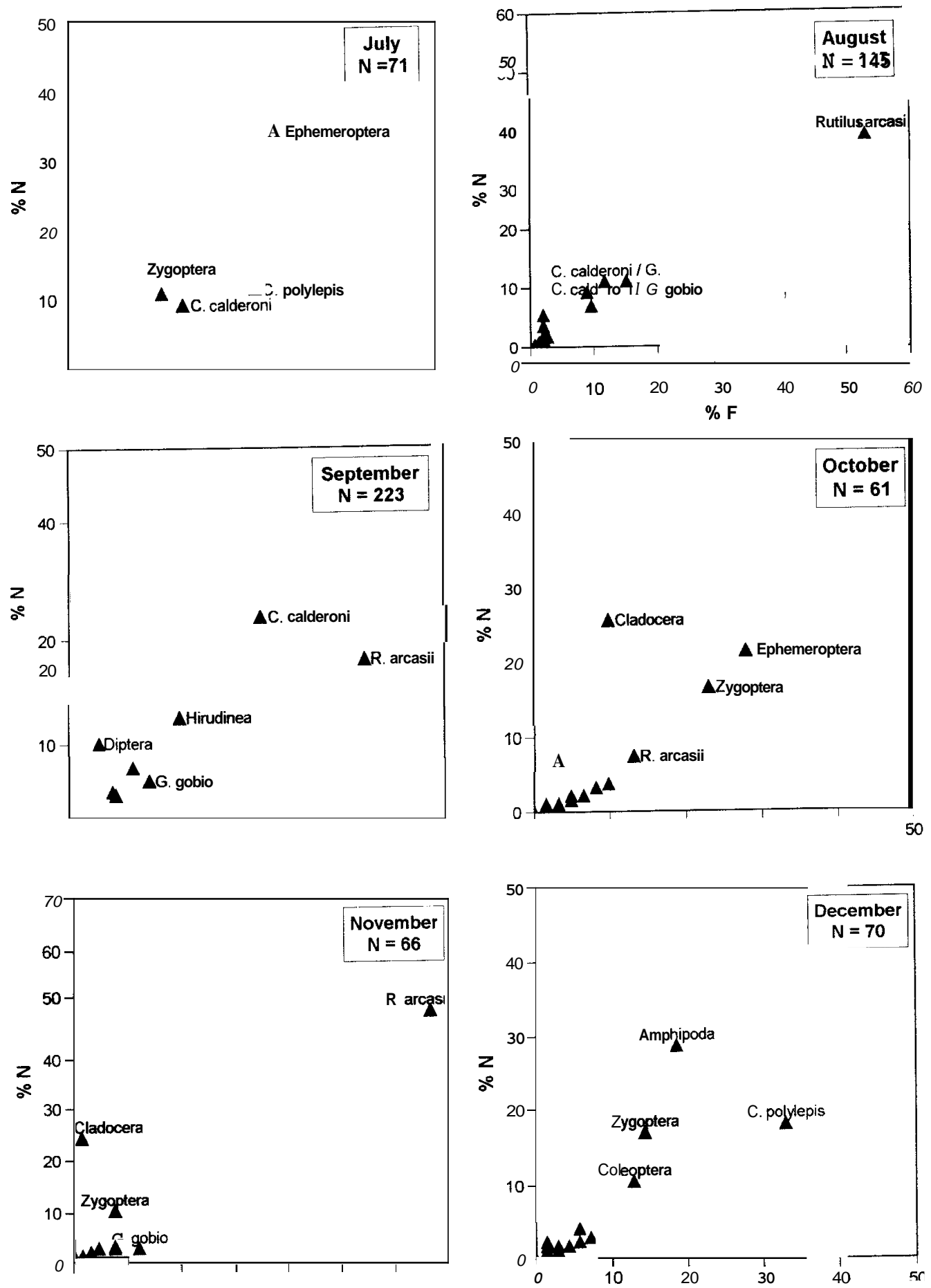

Figure 8. (Continuation) 
graphy also records very different results on this point. So whilst Mann (1985) and Eklov \& Hamrin (1989) record a significant absence of food in autumn, Lawler (1965), Mann (1976) and Holland \& Huston (1984) mention this in summer. Santamaria (1995) observes up to $79.8 \%$ empty stomachs in winter. In contrast Martinez (1985) points to a decrease in empty stomachs from February to September and Elvira et al.(1996) obtain a constant value for empty stomachs throughout the year with $28.2 \%$. In the Esla basin the proportion of empty stomachs is below 50\% in every month except February and March (coinciding with the period prior to reproduction).

Other studies only give the mean value as in the case of Frost (1954) - 45.68\% empty - ,Diana (1979) - 47\% -, below the value obtained in this study for all the specimens $(54.2 \%)$, but with wide variations. Alessio (1983) also recorded great seasonal variations, although with $31 \%$ of the total with empty stomachs.

The fact that the proportion of stomachs containing food in the Esla basin is relatively high seems logical when considering that they are feeding of a wide prey-spectrum. Pike have been considered opportunists and very flexible in their feeding habits (Chapman et al, 1989; Adams, 1991, Beaudoin et al., 1999). This means that they are capable of ingesting all the prey available in their environment.

In fact, the feeding spectrum of pike in the study area was very wide, as corresponds to a generalist predator and in a recently colonised area (Pena, 1986). In general, it is the widest spectrum found for pike among those in the bibliography, although the size range analyzed is also the widest and the representation of invertebrates in the diet is the highest. Invertebrate species belonging to 21 groups have been found, the most varied diet found for pike, as for I am awareamongst those consulted. Data comparisons have been made with 10 groups represented (Healy, 1956), and with 8 Kennedy (1969) and Holland \& Huston (1985). Many studies state that the presence of invertebrate prey was testimonial (Frost, 19.54, Toner, 1959,
Shnchez-Isarria et al., 1988, Le Louarn \& Bagliniere, 1985, Sostoa \& Lobón-Cerviá, 1989, Stephenson \& Momot, 1991, Kangur \& Kangur, 1998).

Pike also feed on 13 species of fish. Comparable results in Europe can only be found in Alessio (1975), Mann (1976) and Le Louarn \& Bagliniere (1985).

The varied food-spectrum can indicate an increasing population with access to a wide variety of prey but still at the generalist diet stage according to Tokeshi's (1991) interpretation of the Costello (1990) method, used in this study. Rincon et al. (1990) and Velasco (1994) point out in various studies on the Douro basin that the number of species as well as the diversity of communities and the number of specimens decreases in places where pike is present. This indicates that the age of the colony can influence food availability. Elvira et al. (1996) state that they specialise when they have no other resources (as in the case of the Ruidera lagoons) or die out (Daimiel lagoons).

\section{Influence of the capture stretch on the diet}

As already described in detail, the similarity in diet of the different stretches is very high, both qualitatively and quantitatively. In spite of this peculiarities due to the presence of prey in each stretch can be appreciated. Although they are ingested in small numbers and with low frequency, they are characteristic of each area.

The fact that the distinguishing elements are prey with low representation and that all areas participate in most prey, indicates generalist feeding, as interpreted by Tokeshi (1991) who used Costello's (1990) method, the same chosen for this study. The feeding opportunism of the species is also observed on capturing prey exclusive to each stretch. All this corroborates the feeding flexibility of this species as also observed by Chapman et al. (1989) and Adams (1991).

In addition, variations in the diet of nearby areas have also been observed by other authors: Toner (1959), Bracken (1973), Mann (1976, 1982), Craig \& Smiley (1986) and Santamaria (1993, 1995). 


\section{Seasonal changes in the diet}

Changes in the representation of the different taxa, observable in the total monthly study, above all those that are more influenced by the season, confirm the feeding opportunism of this species. (Adams, 1991).

It has also been suggested that this species is capable of rapidly changing its food selection in response to changes in the abundance and vulnerability of available prey (Mann, 1982), which is supported by this study. The fact that the frequency of specimens only ingesting invertebrates increases at hatching time or during demographic explosions of specific groups (in spring and autumn) also stands out.

In addition, changes observed in diversity and uniformity throughout the year suggest low prey selection. Prey use is gape limited.

These facts can confirm the low selectivity of pike without need to analyse its prey availibility. Chapman et al. (1989) assure that pike is an opportunist predator capable of modifying its feeding strategies in response to environmental changes. In reference to this, Sostoa \& LobónCerviá (1989) found a significant correlation between diet and abundance of prey.

Mann (1982) demonstrates the complexity of factors in the evaluation of the variation in the diet, mainly prey availability, selection and seasonal abundance. Mauck \& Coble (1971) and Wahl \& Stein (1988) introduce the concept of "vulnerability", as opposed to the simple seasonal variation in food proposed by Frost (1954), Healy (1956) and Lawler (1965).

Nevertheless, some authors have demonstrated the rejection of those prey with anti-predator morphological structures (Beyerle, 1978; Eklov \& Hamrin, 1989) concurring with Wolfert \& Miller (1978) and Navarro \& Johnson (1992), who suggest the selection of prey with soft radii as opposed to those with bony ones. The only prey species in this study that could be considered "armed" are carp and black bass. These species are ingested on few occasions and in small numbers.

Thus, the use of every type of habitat, moving frequently, as shown by Chapman \&
Mackay (1984) would make feeding on a large number of prey easy. This reinforces Savino \& Stein's (1979) statement that pike are capable of successfully catching prey in heterogeneous habitats.

\section{ACKNOWLEDGEMENTS}

We wish to thank the Wildlife Services of the Castile and León Regional Government in León and Zamora for the facilities provided and help in catching specimens; R. Aguado for recording data; R. Ontañón and Dr. Luis Calabuig for their help with data processing and interpretation results; and Dr. Mazé for patiently correcting this manuscript.

\section{REFERENCES}

ADAMS, C.E. 1991 . Shift in pike, Esox lucius L., predation pressure following the introduction of ruffe, Gymnocephalus cernuus (L.) to Loch Lomond. J. Fish Biol., 38: 663-667.

ALESSIO, G. 1975. Richerche sulla biologia del luccio, Esox lucius L. (Osteichthyes, Esocidae), in Lomellina Occidentale ed in un "Valle" Veneta. Boll. Pesca Piscic. Idrobiol., 30 (2): 235-2.56.

ALESSIO, G. 1983. Quelques aspects de la biologie et de l'élevage du brochet (Esoxlucius L.) en Italie. En: Le brochet: gestion duns le miliea naturel et élevage. Billard, R. (ed): 238-296. INRA Publ., Paris.

ARRIGNON, J. 1966. Action d'une population de brochets (Esoxlucius L.) sur le cheptel trutticole hébergé par les eaux de premiere catégorie. Bulletin de l'Ecole Nationule Supérieure Agronomique de Nancy, 8 (1): 39-47.

BEAUDOIN, C.P., W.M. TONN, E.E. PREPAS \& L.I. WASSENAAR. 1999. Individual specialization and trophic adaptability of northern pike (Esoxlucius): an isotope and dietary analysis. Oecologia, 120: 386-396.

BEYERLE, G.B. 1978. Survival, growth and vulnerability to angling of northern pike and walleyes stocked as fingerlings in small lakes of bluegills or minnows. American Fisheries Society, Special Publication, 11: 135-139

BOWEN, S.H. 1984. Quantitative description of the diet. In: Fisheries techniques. Nielsen, L.A. \& D.L. 
Johnson (ed.): 325-336. American Fisheries Society. Maryland.

BRACKEN, J.J. 1973. The age and growth of pike Esox lucius from Irish trout rivers. Irish Fisheries Invest.(A), 12: 3-15.

COSTELLO. M.J. 1990. Predator feeding strategy and prey importance: a new graphical analysis. J. Fish Biol., 36: 261-263.

CRAIG, J.F. \& K. Smiley. 1986. Wayelle, Stizostedion vitreum, and northern pike, Esox lucius, populations in three Alberta lakes. J.Fish Biol.29: 67-85.

CHAPMAN, C.A. \& W.C. Mackay. 1984. Versatility in habitat use by a top aquatic predator, Esox lucius L. J. Fish Biol., 25: 109-115.

CHAPMAN, L.J., W.C. Mackay \& C.W. Wilkinson. 1989. Feeding flexibility in northern pike (Esox lucius): Fish versus invertebrate prey. Can. J. Fish. and Aquat. Sci., 46: 666-669.

DAVID, H.A., H.O. HARTLEY \& E.S. PEARSON. 1954. The distribution of the ration in a single normal sample of range to standard deviation. Biometrika, $41: 482-493$.

DERVIN, C. 1988. Comment interpréter les résultats d'une analyse factorielle des correspondances? STAT-ITCF. Paris. 68 pp.

DESSELLE, J.L. 1990. Analyses multivarie'es sous contraintes: Presentation a partir d'exemples, realisation practique a l'aide du logiciel Biomeco. Mémoire din d'études D.A.A. E.N.S.A. Montpellier. $30 \mathrm{pp}$.

DIANA, J.S. 1979. The feeding pattern and daily ration of a top carnivore, the northern pike (Esox lucius). Can. J. Zool., 57: 2121-2127.

DOMÍNGUEZ, J. 1996. Contribucidn al conocimiento de la biología del lucio (Esox lucius) en un área de reciente colonizacion: Cuenca del Esla. Tesis Doctoral. Universidad de León. 230 pp.

DOMÍNGUEZ, J., J.C. PENA \& G. GONZÁLEZ. 1989. First occurrence of hermafrodite pike, Esox lucius L. in the Esla basin (Spain). J. Fish Biol., 34: 973-975.

EKLOV, P. \& S.F. HAMRIN. 1989. Predatory efficiency and prey selection: interactions between pike Esox lucius, perch Perca fluviatilis and rudd Scardinus erythrophthalmus. Oikos, 56: 149-156.

ELVIRA, B., G.G. NICOLA \& A. ALMODOVAR 1996. Pike, Esox lucius, and red swamp crayfish, Procambarus clarkii: a new case of predator-prey relationship between aliens in central Spain. J. Fish Biol.

FROST, W. 1954. The food of pike, Esox lucius L., in Windermere.Joumal of Animal Ecology, 23: 339-360.
HEALY, A. 1956. Pike (Esox lucius L.) in three Irish Lakes. The Scientijic Proceedings of the Royal Dublin Society, 27: 51-63.

HOLLAND, L.E. \& M.L. HUSTON. 1984. Relationship of young-of-the-year northern pike to aquatic vegetation types in backwaters of the upper Mississippi river. North American Journal of Fisheries Management, 4: 514-522.

HOLLAND, L.E. \& M.L. HUSTON. 1985. Distribution and food habits of young-of-the-year fishes in a backwater lake of the upper Mississippi river. J. Freshw. Ecol., 3 (1).

ILLIES, J. \& L. BOTOSANEANU. 1963. Problemes et méthodes de la classification et de la zonation écologique des eaux courrantes, considerées surtout du point de vue faunistique. Verh. Intemat. Verein. Limnol., 12: 1-57.

KANGUR, A. \& P. KANGUR. 1998. Diet composition and size-related changes in the feeding of pikeperch, Stizostedion lucioperca (Percidae) and pike, Esox lucius (Esocidae) in the Lake Peipsi (Estonia). Italian Journal of Zoology, 65 Suppl.: 255-259.

KENNEDY, M. 1969. Irish pike investigations: spawning and early life history. Irish Fisheries Invest., A (5):4-33.

KIPLING, C., 1983. Changes in the population of pike (Esoxlucius) in Windermere from 1944 to 1981.J. Anim. Ecol., 52: 989-999.

LARSEN, K. 1966. Studies on the biology of Danish stream fishes. II. The food of pike (Esox lucius L.) in trout stream. Meddr Danm. Fisk. og Havunders, 4: 271-326.

LAWLER, G.H. 1965. The food of the pike, Esox lucius, in Heming lake, Manitoba. J. Fish. Res. Board Can., 22 (6): 1357-1377.

LE LOUARN, H. \& J.L. BAGLINIERE. 1985. Quelques élements de la biologie du brochet (Esox lucius L, 1758) sur une riviere à salmonidis: Le Scorff. Cybium, 9 (1): 75-87.

M A " ,R.H.K. 1976. Observations on the age, growth, reproduction and food of the pike Esox lucius (L.) in two rivers in southern England. J. Fish Biol., 8: 179197.

MANN, R.H.K. 1982. The annual food consumption and prey preferences of pike (Esoxlucius) in the river Frome, Dorset. J. Anim. Ecol., 51: 81-95.

MANN, R.H.K. 1985. A pike management strategy for a trout fishery. J. Fish Biol., 27 (A): 227-234.

MARGALEF, R. 1972. Ecología marina. Fundación La Salle. Ed. Dossat. Caracas. 711 pp.

MARTÍNEZ, J.B. 1985. El lucio, treinta años después. Vida Silvestre, 3: 80-92. 
MAUCK, W.L. \& D.W. Coble. 1971. Vulnerability of some fishes to northern pike (Esox lucius) predation. J. Fish. Res. Board Can., 28: 957-969.

MUNRO, W.R. 1957. The pike of Loch Choin. Freshwater and Salmon Fisheries Research, 16: 16pp.

NAVARRO, J.E. \& D.L. Johnson. 1992. Ecology of stocked northern pike in two lake Erie controlled wetlands. Wetlands, 12 (3): 171-177.

PENA, J.C. 1986. Introducción y expansion del lucio (Esox lucius L., 1758) en la Peninsula Ibérica: síntesis general y estudio de las poblaciones en la cuenca del Esla. Limnetica, 2: 241-251.

PENA, J.C., G. González \& V. Hernandez. 1991. Descripción de una trampa para captura de reproductores de lucio (Esox lucius). Comunicacidn III Jomadas Ictiol. Iber: Perlora. 1 pp.

PIELOU, E.C. 1966. The measurement of diversity in differents types of biological collections. J. Theor. Biol., 13: 131-144.

RINCÓN, P.A., J.C. VELASCO, N. GONZÁLEZSANCHEZ \& C. POLLO. 1990. Fish assemblages in small streams in western Spain: The influence of an introduced predator. Archiv f. Hydrobiol., 118 (1): 81-91.

SANCHEZ-ISARRIA, M.A., L. CABANAS, E. ESPINOSA, E. TUTOR \& M. SERRANO. 1988. Análisis de la composición de la dieta natural del lucio (Esox lucius L.) de tamaño mayor de $30 \mathrm{~cm}$. Actas Col. Luso-Esp. Ecol Bacias Hidrogr. e Rec. Zool: : 359-364.

SANTAMARÍA, A. 1993. Alimentación del lucio en invierno. Trofeo Pesca, I (7): 22-27.

SANTAMARÍA, A. 1995. Descaste y estudio de las poblaciones de lucios en el Tormes. Trofeo Pesca, 24: 40-44.

SAVINO, J.F. \& R.A. STEIN. 1979. Behavioural interactions between fish predators and their prey: effects of plant density. Animal Behaviour, 37: 311-321.

SHANNON, C.E. \& C.D. WEAVER. 1949. The mathematical theory of comunication. University of Illinois. Press Urbana.

SNEATH, P.H.A. \& R.R. SOKAL. 1973. Numerical taxonomy the principle and practice of numerical classification. W.H. Freeman. San Francisco.

SNOW, H.E. 1974. Effects of stocking northern pike in Murphy flowage. Wisconsin Department of Natural Resources, Technical Bulletin, $\mathrm{n}^{\circ}$ 79:1-20.

SOKAL, R.R. \& F.J. ROHLF. 1981. Biostatistics. 2" ed. W.H. Freeman and Co. San Francisco

SORENSEN, T. 1948. A method of stablishing groups of equal amplitude in plant sociology based on similarity of spesies content and its application to analysis of the vegetation on Danish Commons. Biologiske Skrifter, 5 (4): 1-34.

SORBE, J.C. 1972. Ecologie et ethologie alimentaire de l'ichthyofaunechalutable du plateau continental sud Gasgogne. Tesis 3e. Cycle. Univ. AixMarseille, $125 \mathrm{pp}$.

SOSTOA, A. \& J. LOBÓN-CERVIÁ. 1989. Observations on feeding relationships between fish predators and fish assemblages in a Mediterranean stream. Regulated Rivers: Research and Management, 4: 157-163.

STEEL, R.G.D. \& J.H. TORRIE. 1985. Bioestadística: Principios fundamentales. McGraw-Hill Ed. México. 622 pp.

STEPHENSON, S.A. \& W.T. MOMOT. 1991. Foods habits and growth of walleye, Stizostedion vitreum, smallmouth bass, Micropterus dolomieui, and northern pike, Esox lucius, in the Kaministiquia river, Ontario. Canadian Field-Naturalist, 105 (4): 517 521.

TOKESHI, M. 1991. Graphical analysis of predator feeding strategy and prey importance. Freshwater Forum, 1: 179-183.

TONER, E.D. 1959. Predation by pike in three Irish lakes. Department's Report on the Sea and Inland Fisheries: 1-7.

TREASURER, J.W. 1988. Measurement of regurgitation in feeding studies of predatory fishes. J. Fish Biol., 33: 267-271.

VELASCO, J.C. 1994. Atlas de los peces de las provincias de Salamanca y Zamora. Valoracidn de especies y tramos fluviales. Tesis Doctoral. Universidad de Salamanca. Salamanca.

VOOREN, C.M. 1972. Ecological aspects of the introduction of fish species into natural habitats in Europe, with special reference to the Netherlands: A literature survey. J. Fish Biol., 4: 565-583.

VOSTRADOWSKY, J. 1977. The age and growth of pike (Esox lucius L.) in the artificial reservoir Lipno. Práce Vurh Vodnany, 10: 21-46.

WAHL, D.H. \& R.A. STEIN. 1988. Selective predation by three esocids: the role of prey behavior and morphology. Trans. Amer. Fish. Soc., 117: 142-151.

WEBER, G. 1991. Analyse statistique de peuplements lombriciens en milieu forestier. Rapport du stage au laboratoire de Zooécologie du sol (INRA/CNRS). Montpellier.

WINDEL J.T. \& S.H. BOWEN. 1978. Methods for study of fish diets based on analysis of stomach 
contents. In: Methods for assessment of fish production infresh waters. Bagenal, T. (ed.): 219-226. Blackwell Scientific Publications. Oxford.
WOLFERT, D.R. \& T.J. MILLER. 1978.Age, growth, and food of northern pike in eastern lake Ontario. Trans. Amer. Fish. Soc., 107 (5):696-702. 